\title{
Intercropping technology to increase cropping index in Central Java, Indonesia
}

\author{
Yennita Sihombing*, and Rima Purnamayani \\ Indonesia Center for Agriculture Technology Assessment and Development, Tentara Pelajar 10, \\ Bogor, West Java, Indonesia
}

\begin{abstract}
One of the influencing factors to increase the productivity of agricultural commodities is intensive intercropping (so-called Turiman in this paper) implementation in local agroecosystem. The study aimed to determine the perception of intercropping implementation and farming analysis to increase cropping index in Pemalang Regency, Central Java Province. This study was carried out in the Kwagen village, Bodeh SubDistrict, Pemalang Regency, Central Java Province with thirty respondents. Primary data were collected then analyzed for each indicator. Data were simply analyzed based on the percentage of answers on the indicators. Meanwhile, secondary data were analyzed qualitatively using the Desk Research Method. The results showed that there were $63.3 \%$ farmers understood and applied intercropping technology (Turiman), 13\% farmers understood but did not implement Turiman, and 20\% farmers did not know and did not implement Turiman. By implementing Turiman, farmers obtained the benefits in increasing production, optimizing land use, saving production costs, and generating income showed by the increase of $\mathrm{BC}$ ratio from 1.11 (no technology application) to 1.78 (Turiman application).
\end{abstract}

\section{Introduction}

The government through the Ministry of Agriculture continues to encourage the acceleration of food self-sufficiency through the special effort program for three main commodities, namely rice, corn, and soybeans. The program focuses on increasing land production and productivity through increasing planting area, increasing the cropping index, and implementing site-specific agricultural technology innovations.

Cropping Index (CI) is the average planting and harvesting period in one year on the same land [1]. Increasing the CI can be performed through the utilization of water resources around dryland locations, rainfed rice fields, and swamps [2]. Increasing the cropping index is largely determined by the potential availability of irrigation water and optimization of land use. Agricultural innovations support for increasing cropping index in dryland and rainfed rice fields depend on diversity and climate change as a dynamic and continuous natural process [3].

Increasing the cropping index of rice and other commodities can be performed in the second planting season by utilizing rainfall and additional water pumps from deep wells,

* Corresponding author: yennita.sihombing86@gmail.com 
shallow wells, river water, or ditch checks. Superior varieties and components of production technology according to location characteristics will support the success of increasing the cropping index in the second planting season [4].

One of the factors influencing the increase in cropping index is the use of superior varieties. Various high-yielding varieties become alternatives for farmers according to agroclimatic conditions. However, the maximum potential of new high-yielding varieties is achieved under suitable growing environmental conditions [5]. Productivity is one indicator of variety adaptation [6].

Efforts to increase land productivity can be performed through optimizing land use with the introduction of location-specific technological innovations in accordance with environmental conditions and the ability of local farmers to effectively and efficiently increase the cropping index. The introduction of technological innovations must be disseminated to increase crop productivity by taking into account the potential and available opportunities. One of the technological innovations to increase the cropping index is intercropping.

Intercropping is one way to increase crop productivity and land use efficiency [7]. Intercropping is a cropping pattern on a plot of land that is planted with more than one type of plant at the same time [8]. Intercropping can also reduce the risk of crop failure and Plant Pests (OPT) attacks because there are various types of plants. The advantage of intercropping is up to $81 \%$ compared to monoculture [9]. For example, corn-upland rice intercropping is mutually beneficial because rice at low light intensity can still produce well [10].

Although intercropping has become one of the programs of the Ministry of Agriculture, in reality it was found that farmers in some locations are still reluctant to continue the crop intercropping pattern in their farming. This study aimed to find out the perception of intercropping implementation and farming analysis to increase cropping index in Kwagen Village Bodeh Sub-District, Pemalang Regency, Central Java Province. This study will enrich the literature about the perception of intercropping implementation because of the lack references about that.

\section{Methods}

This study was carried out in Kwagen Village, Bodeh Sub-District, Pemalang Regency Central Java Province in August 2019. Pemalang Regency, Central Java Province is located on the north coast of Java Island. Astronomically, Pemalang Regency is located between $109017^{\prime} 30^{\prime \prime}-109040^{\prime} 30^{\prime \prime}$ East Longitude and 80 52' 30" - $7020^{\prime} 11^{\prime \prime}$ South Latitude.

Data were collected through the interview method on 30 members of the farmer group cooperator of the intercropping (maize and rice) program using purposive random sampling. The data collected was primary data obtained through questionnaires (a list of written questions related to research variables studied) and interviews. Primary data consist of characteristics of farmers (age, length of education, farming experience), farmers' perceptions of intercropping technology, and farming analysis before and after implementation of intercropping technology. The farmer's perception was measured through evaluation activities The activity indicators used to see respondents' perceptions of intercropping technology innovations were farmers' knowledge of intercropping technology and the application of the technology by farmers. The collected data were then tabulated and analyzed based on each indicator. Secondary data collected is the geographical condition of the study location by literature study. Data were analyzed simply, based on the percentage of answers on established indicators and equipped while secondary data were analyzed qualitatively using the Desk Research Method.

Analysis of the $\mathrm{B} / \mathrm{C}$ ratio is used to show the comparison between revenue and costs, so that it can be known whether the farming business being cultivated is profitable or not. $\mathrm{B} / \mathrm{C}$ 
Ratio (Benefit Cost Ratio) is a measure of the comparison between income (Benefit $=\mathrm{B}$ ) and Total Production Cost $($ Cost $=C)$. Within the limits of the amount of the $B / C$ value, it can be seen whether a business is profitable or not. Formula: $\mathrm{B} / \mathrm{C}$ ratio $=$ Total Profit (B) $/$ Total Production Cost (TC) If $\mathrm{B} / \mathrm{C}$ ratio $>0$, the business is feasible If $\mathrm{B} / \mathrm{C}$ ratio $<0$, the business is not feasible or loses [10].

\section{Results and discussions}

\subsection{General condition}

Pemalang Regency has a varied topography where the northern part is a coastal area with an altitude ranging from 1-5 meters above sea level, the middle part is a fertile lowland with an altitude of 6-15 m above sea level and the southern part is a highland and fertile mountain with cool air at an altitude of 16-925 $\mathrm{m}$ above sea level. This regency has the potential of the agricultural sector with 38,617 hectares of rice fields and 23,813 hectares of dry land. The prominent commodities for food crops in this regency are Rice, Cassava, Maize, Vegetables, Shallots, Red Chili, and Cucumbers while fruits are Pineapple, Banana, and Mango (https://www.pemalangkab.go.id/ profile-district-pemalang)

In Kwasen Village, Bodeh Sub-District, Pemalang Regency, the majority consists of rainfed rice fields covering $43.32 \%$ of the total rice fields. Meanwhile, based on its type, Kwasen Village has dry land six times wider than rice fields, namely 723.95 ha. The population majority $(63.6 \%)$ had 9 years of education. $86.4 \%$ farmers aged 28 to 64 years or including productive age. In this village, $37.8 \%$ were farmers and $40.86 \%$ were farm laborers [12]. Inventory of rainfed rice fields to increase cropping index in fifteen districts in Central Java Province had an area of 14,325.3 ha [13].

\subsection{Characteristics of farmers}

The first aspect as an object in this study was the characteristics of farmers implementing the intercropping technology (turiman). The characteristics of farmers were focused on age, education, and farming experience. These three variables include demographic characteristics $[14,15,12,16,17]$.

Age was calculated from birth to the time of becoming a respondent with categories: (1) young $(<45$ years), (2) intermediate ( $45-55$ years), and (3) old ( $>55$ years). Education was measured based on the time taken by farmers in attending formal schools based on levels from elementary school to college (years). The measurement results were categorized into (1) low (less than 7 years or equivalent to elementary school graduation), (2) intermediate (more than 7 years to 10 years or equivalent to junior high school graduation), and (3) high more than 10 years).

Farming experience shows how long farmers have been involved in the cultivation, production, business intricacies, and marketing of agricultural products [18]. The experience was divided into (1) beginner experience (less than 10 years), (2) intermediate experience (range 10 - 20 years), and (3) advanced experience (more than 20 years). More detailed information on the three variables are presented in Table 1. 
Table 1. Characteristics of farmers implementing intercropping in Kwajen Village, Central Java

\begin{tabular}{|l|c|c|}
\hline \multicolumn{1}{|c|}{ Age (Years) } & Total (People) & Percentage (\%) \\
\hline Young (<45 years) & 16 & 53.3 \\
\hline Intermediate (45 -55 years) & 9 & 30.0 \\
\hline Old ( $>55$ years) & 5 & 16.7 \\
\hline Total & $\mathbf{3 0}$ & $\mathbf{1 0 0}$ \\
\hline Standard Deviation & $\mathbf{4 . 5 5}$ & $\mathbf{1 5 . 1 5}$ \\
\hline \multicolumn{1}{|c|}{ Education (Years) } & Total (People) & Percentage (\%) \\
\hline Low (<7 years) & 12 & 40.0 \\
\hline Intermediate $(7-10$ years) & 9 & 30.0 \\
\hline High $(>10$ years) & 9 & 430.0 \\
\hline Total & $\mathbf{3 0}$ & $\mathbf{1 0 0}$ \\
\hline Standard Deviation & $\mathbf{1 . 4 1}$ & $\mathbf{4 . 7 1}$ \\
\hline Farming Experience (Years) & Total (People) & Percentage (\%) \\
\hline New (<10 years) & 5 & 16.7 \\
\hline Intermediate $(10-20$ years) & 6 & 20.0 \\
\hline Advanced $(>20$ years) & 19 & 63.3 \\
\hline Total & $\mathbf{3 0}$ & $\mathbf{1 0 0}$ \\
\hline Standard Deviation & $\mathbf{6 . 3 8}$ & $\mathbf{2 1 . 2 6}$ \\
\hline
\end{tabular}

Source: Processed Data (2019)

Table 1 showed 30 respondents showing relatively homogeneous age (standard deviation $=4.55)$, with the minimum and maximum ages were in the productive category (15-64 years) [12]. According to [15], farmers are still working in old age because they do not have a pension, so they must continue to work as long as no one guarantees their life. Based on the education side, the standard deviation was 1.41 meaning the mean value (average) was obtained accurately. Education determines the competence of farmers in carrying out agricultural activities and the quality of farmers [17].

According to [19], age and education level had a significant influence in adopting technological innovations. In terms of farming experience, the standard deviation value was quite large, namely 6.38. This means that the greater the value of the standard deviation, the more diverse the values of the variables tested. In other words, the high mean value showed the false parameter to represent all data. Mulyasa [20] stated that the development of thinking skills is in accordance with age. This shows that the older the age, the more experience obtained so that the competence in farming will increase.

\subsection{Farmers perception on intercropping technology}

Technological innovation is proven to increase agricultural and farmer production in supporting the realization of food security. The innovation in question consists of inventions (new findings) and the dissemination process [21]. As the implementation of technological innovations to increase the $\mathrm{CI}$ of rice, corn, and soybeans in rainfed rice fields, inventory and identification of land use and infrastructure as well as water management can be synergized to increase crop production.

Intercropping technology was measured through evaluation activities. The evaluation aimed to find out the farmers perceptions of the technological innovations applied in the study. Farmers perception shows the organization and interpretation of the stimulus received by farmers before making a decision to accept or reject the innovation. Perception is the second stage in the adoption process [22].

Increasing the cropping index through the implementation of intercropping was performed by demonstrating the intercropping pilot based on the implementation instructions 
issued by [23] and adjusted according to local conditions. The implementation of the Turiman maize and rice cropping model or system is presented in Figure 1. The Direktorat Jenderal Tanaman Pangan (Directorate General of Food Crops) intercropping uses very tight spacing for both corn and rice so that each population increased to $130 \%$ or both total to $260 \%$. Based on the interview with the farmer, crop-cuts yield implementing intercropping technology innovation based on the instructions from the Ditjentan was 5.5 tons/ha meaning that the yield was good because land productivity can be increased so CI can also increase.

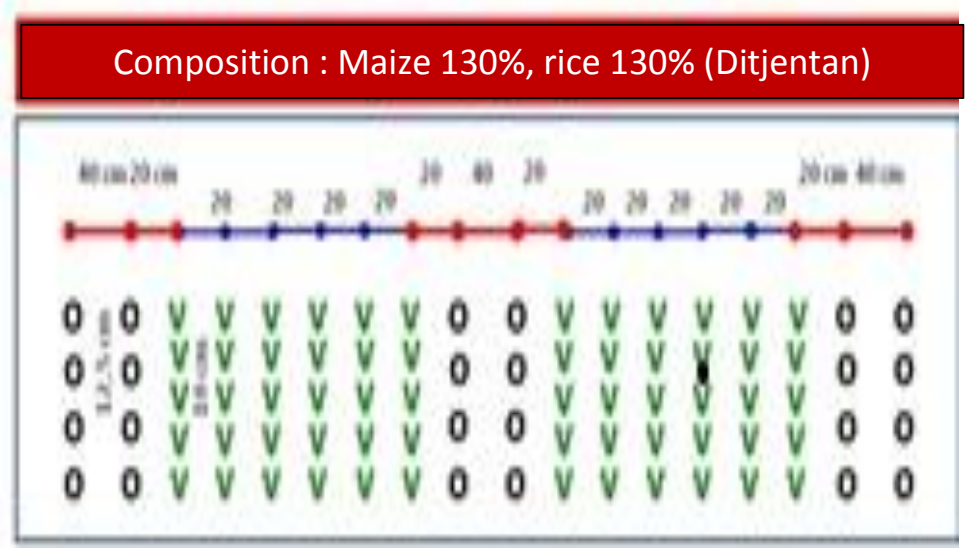

Fig 1. Ditjentan intercropping [23]

The results of farmer' perceptions are described in Figure 2. It showed $20 \%$ of farmers did not know intercropping technology while $80 \%$ knew. $13 \%$ of farmers knew intercropping technology but did not implement it while $63.3 \%$ knew and implement it. $20 \%$ did not know and implement intercropping technology. There were farmers who didn't know about intercropping technology because they were not the cooperator farmers of the program. Meanwhile, the farmer who knew but did not implement the technology, because they they still doubted the advantages of implementing the intercropping system and have already were satisfied with the monoculture systems. From this data, almost all farmers in Kwagen Village Bodeh Sub-District Pemalang Regency Central Java Province knew and implemented intercropping technology (Turiman). The majority of farmers believed that the introduction of intercropping technology could provide additional benefits for farmers thereby increasing household income.

This may be due to the fact that these farmers have not directly experienced the benefits of implementing the intercropping technology. According to [24], farmers perceptions are influenced by internal and external factors namely 1) low-income levels; 2) incomprehensive technological innovation; 3) ineffective dissemination of technological innovation; and 4) farmers still face various problems, both internal and external. Through the implementation of innovation, farmers are able to achieve their goals better or at lower costs [25]. According to [26], the public as users of technological innovation must be more selective in choosing the technology used because it is related to the costs incurred. 


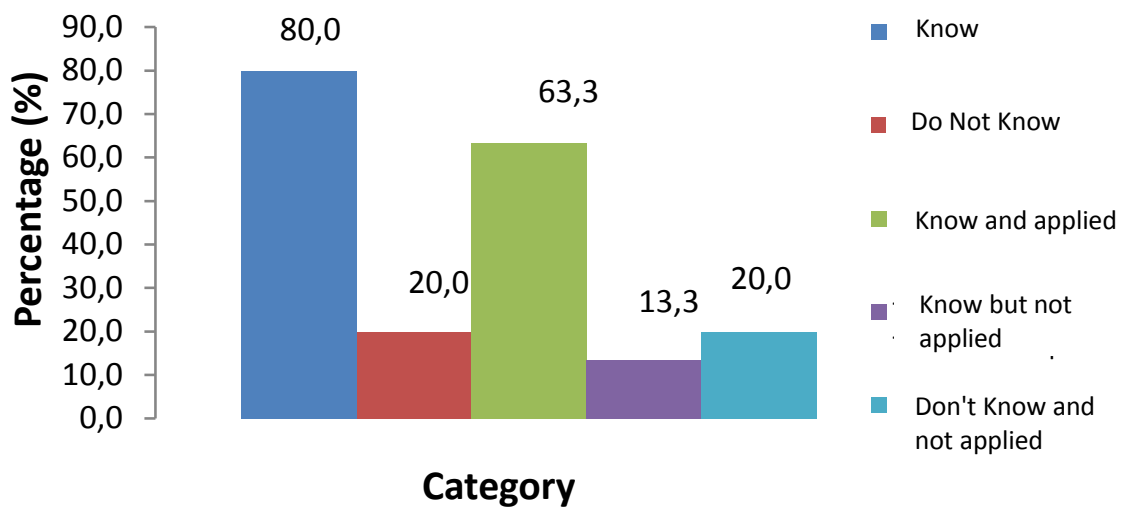

Fig 2. Number of farmers implementing intercropping technology

\subsection{Farming analysis before and after implementing intercropping technology}

$\mathrm{BC}$ ratio analysis is used to show the comparison between revenues and costs so that it can be known whether farming is profitable or not. If the $\mathrm{B} / \mathrm{C}$ value is more than one, the farm is categorized as profitable. Implementation of intercropping technology can increase production and income based on farming feasibility analysis before and after implementing Turiman as presented in Table 2 .

Table 2. Farming analysis before and after implementing Turiman

\begin{tabular}{|c|c|c|c|c|c|c|}
\hline \multirow[b]{2}{*}{ Input/Output } & \multicolumn{3}{|c|}{ Before Implementing Turiman } & \multicolumn{3}{|c|}{ After Implementing Turiman } \\
\hline & Vol & $\begin{array}{l}\text { Unit } \\
\text { Price }\end{array}$ & Total & Vol & $\begin{array}{l}\text { Unit } \\
\text { Price }\end{array}$ & Total \\
\hline Seeds $(\mathrm{kg})$ & 66 & 7,000 & 462,000 & 50 & 7,000 & 350,000 \\
\hline \multicolumn{7}{|l|}{ Fertilizer } \\
\hline Urea $(\mathrm{kg})$ & 200 & 2,000 & 400,000 & 200 & 2,000 & 400,000 \\
\hline SP36 (kg) & 100 & 2,000 & 200,000 & 250 & 2,000 & 500,000 \\
\hline $\mathrm{KCl}(\mathrm{kg})$ & 100 & 2,000 & 200,000 & 100 & 2,000 & 200,000 \\
\hline Insecticide (liter) & 3 & 80.000 & 240,000 & 3 & 80,000 & 240,000 \\
\hline \multicolumn{7}{|l|}{ Herbicide } \\
\hline Others & & & & 1 & 125,000 & 125,000 \\
\hline $\begin{array}{l}\text { Production input } \\
(\mathrm{Rp} / \mathrm{ha})\end{array}$ & 1 & 800,000 & 800,000 & 1 & $1,500,000$ & $1,500,000$ \\
\hline $\begin{array}{l}\text { Labor } \\
\text { (mandays/ha) }\end{array}$ & 50 & 60,000 & $3,000,000$ & 50 & 60,000 & $3,000,000$ \\
\hline $\begin{array}{l}\text { Total Cost } \\
(\mathrm{Rp} / \mathrm{ha})\end{array}$ & & & $5,302,000$ & & & $6,315,000$ \\
\hline $\begin{array}{l}\text { Production } \\
(\mathrm{kg} / \mathrm{ha})\end{array}$ & 3,500 & 3,200 & $11,200,000$ & 5,500 & 3,200 & $17,600,000$ \\
\hline Profit (Rp/ha) & & & $5,898,000$ & & & $11,285,000$ \\
\hline $\mathrm{BC}$ ratio & & & 1.11 & & & 1.78 \\
\hline
\end{tabular}

Source: Processed Data, (2019) 
Table 2 showed that the production of plants/ha after implementing the intercropping technology reached $5,500 \mathrm{~kg} / \mathrm{ha}$ at a price of $\mathrm{Rp} .3,200 / \mathrm{kg}$ so that the revenue was $\mathrm{Rp}$. $17,600,000$ and the profit was Rp. 11,285,000. This shows that the profits obtained exceed the total costs incurred by Rp. 6. 315,000. The BC ratio before implementing the intercropping technology was 1.11 while after implementing the intercropping technology was 1.78 . This shows that there is an increase of 0.67 or every Rp. $1,-$ the costs incurred will give a profit of Rp. 1.78. Thus, farming with intercropping technology is profitable for farmers, because it has the potential to increase production and income. This is in line with a study by [27] showing that in three planting seasons, the average net income of farmers in a year was $\mathrm{Rp} 12,178,057$ with a Return on Investment of $75.22 \%$. Thus, planting soybeans as intercrops were economically feasible and financially efficient in the use of capital.

Farming analysis in Pemalang Regency is not much different from the results of a study in [28] in Seluma Bengkulu Regency showing that the introduction of the jajar legowo planting system with corn-soybeans in paddy fields resulted in income from corn was Rp.19,480,000 and from soybean was Rp. 2,920,000 with R/C of 1.83.

In farmer households, the use of agricultural technology innovations is needed to increase the productivity of farmers. Thus, if the income of farmers increases, the food security of households will be stronger and more prosperous [29]. The income will be better if the number of products produced is increasing with relatively fixed production costs. Income is an important factor in determining household expenditures, including family food consumption patterns. If income increases, consumption patterns will be more diverse so that the consumption of food with high nutritional value will also increase [30].

\section{Conclusion}

Most of the farmers in Kwagen Village Bodeh Sub-District Pemalang Regency Central Java Province already known and implemented intercropping technology as well as believed that the introduction of intercropping technology can provide additional benefits for farmers, thereby increasing household income. Farming analysis showed that the implementation of intercropping technology can obtain a profit of $\mathrm{Rp} .11,285,000$ with a B/C of 1.78 . The benefits of intercropping technology (Turiman) in the assisted areas have been felt by farmers in terms of increasing production, increasing income, and increasing ability in implementing technological innovation.

\section{References}

1. S. Nono. Pengembangan Pengelolaan Panen Hujan Mendukung Kemandirian Pangan. Sumber Daya Lahan dan Air. Prospek Pengembangan dan Pengelolaan (ed. Pasandaran, E., Heriawan, R, dan Syakir, M). IAARD Press (2016)

2. H. Syahbudin, R.Purnamayani., U. Humaedah., Y.Apriyana., W.Estriningtyas dan B. Kartiwa. Juklak "Penerapan Inovasi Teknologi Untuk Peningkatan Indeks Pertanaman (IP). Balai Besar Pengkajian dan Pengembangan Teknologi Pertanian, Kementan. Bogor. 28 Halaman (2018)

3. I.W. Harmoko. Gatra iklim terhadap produksi pertanian di Jawa Tengah. Makalah Bintek Dukungan Inovasi Teknologi terhadap Peningkatan IP pajale Spesifik wilayah. 12 Halaman (2017)

4. A. Anshori, D. Riyanto dan Suradal. AgriHealth: Journal of Agri-food, Nutrition and Public Health, 1(2) : 55-61 (2020)

5. A. Minarsih, Prayudi, B., dan Warsito, W. Keragaan beberapa varietas unggul baru padi sawah irigasi dengan menerapkan pengelolaan tanaman terpadu (PTT) di Kabupaten 
Klaten. Seminar Nasional : Menggagas Kebangkitan Komoditas Unggulan Lokal Pertanian dan Kelautan. Fakultas Pertanian Universitas Trunojoyo Madura - Balai Pengkajian Teknologi Pertanian Jawa Tengah. Hlm. 582-587 (2013)

6. Saidah, Syafruddin, dan Pangestuti, R. Daya hasil padi sawah varietas Inpari 24 di beberapa lokasi SL-PTT di Sulawesi Tengah. Prosiding Seminar Nasional Masyarakat Biodiversitas Indonesia, 1(5) : 1147 - 1150 (2015)

7. Susanti, Anwar S, Fuskhah E, Sumarsono. Jurnal Agromedia,. 32(2) : 38-44 (2014)

8. J.P.H. Putra, K.P. Wicaksono dan N. Herlina. Jurnal Produksi Tanaman, 5 (5) : 748-755 (2017)

9. D.T. Hermawati . Inovas, 18(1) : 66-71 (2016)

10. Sajari, I, Elfiana dan Martina. Jurnal S. Pertanian 1 (2) : 116 - 124 (2017)

11. Sution, A. Musyafak, S. Sunardi. Agritep, 8(2) : 130-141 (2020)

12. Nurhasikin. Penduduk Usia Produktif dan Ketenagakerjaan. Tersedia dari: http://kepri.bkkbn. go.id/Lists/Artikel/DispForm.aspx?I D=144 ( 2013)

13. Samijan, T. Prastuti, Karyaningsih, N. Ridha, Sodiq, S. R. Anggi, Warsito dan Abadi. Dukungan Inovasi Teknologi Pertanian Terhadap Peningkatan IP Pajale (Laporan Intern). BPTP Jawa Tengah (2017)

14. W. N. Afandi. Identifikasi karakteristik rumah tangga miskin di Kabupaten Padang Pariaman. Tesis (tidak dipublikasikan). Universitas Andalas. Tersedia dari: http://unand.ac.id/20447/1 (2010)

15. R. Budiartiningsih, Y. Maulida, dan Taryono. Jurnal Ekonomi, 18(1):79-93. (2010)

16. N. K. Andini, D. P. E. Nilakusmawati, dan M. Susilawati. Piramida Jurnal Kependudukan dan Pengembangan Sumber Daya Manusia 9(1) :44-49 (2013)

17. I. Manyamsari, dan Mujiburrahmad. Jurnal Agrisep 15(2): 58-74 (2014)

18. A. Shinta. Ilmu Usahatani. Malang (ID): Univeritas Brawijaya Press (2011)

19. W. Sudana and K. Subagyono. Jurnal Pengkajian dan Pengembangan Teknologi Pertanian, 15 (2): 94-106 (2012)

20. Mulyasa. Kurikulum Berbasis Kompetensi: Konsep, Karakteristik, dan Implementasi. Bandung (ID): .Remaja Rosdakarya (2003)

21. Syahyuti. Tiga Puluh Inovasi Kelembagaan, Adopsi Inovasi Badan Litbang Pertanian. Catatan Perjalanan 40 Tahun Badan Litbang Pertanian. IAARD Press. Jakarta (2013)

22. Y. Hidayat, F. Lala, B. Suwitono, , H. B. AJI, dan B. Bram. Implementasi Teknologi Peningkatan Produktivitas Lahan Kering Di Bawah Tegakan Kelapa di Maluku Utara. Buletin Palma, 21(1) : $11-21$ (2020)

23. Direktorat Jenderal Tanaman Pangan. Program Pengembangan Padi, Jagung, dan Kedelai Tahun 2016 : materi disampaikan pada Workshop Daya Saing dan Indeks Produktivitas Pertanian Provinsi, Jogyakarta 11 Desember 2015 (2015)

24. R. Ramli. Beberapa Faktor Sosial Ekonomi Penyebab Tidak Tuntasnya Penerapan Inovasi Teknologi oleh Petani Tanaman Pangan di Kalimantan Tengah. Prosiding Seminar Nasional: Petani dan Pembangunan Pertanian. Pusat Sosial Ekonomi dan Kebijakan Pertanian. Bogor (ID) (2012)

25. A. Supriatna. Jurnal Agri,. 16(1): 1 - 18. (2012)

26. D. Lestari, E. Turmudi dan D. Suryanti. Jurnal Ilmu-Ilmu Pertanian Indonesi,. 21 (2) : 82-9 (2019)

27. I. Lubis, M. A. Agustira, E. Listia, E.N. Yakoeb, I. Y. Harapan. E. Lubis. Analisis Finansial dan Ekonomi Tanaman Sela (Jagung Dan Kedelai) Pada Areal Tanaman. Seminar Nasional Pengembangan Agribisnis Perkebunan dalam Menghadapi Persaingan Global 04-05 April 2018 DOI: https://doi.org/10.31289/snpapmpg.v1i1.81. http://proceeding.uma.ac.id/index.php/semnasagribisnis (2018) 
28. H. B. Astuti, , R. Hartono, S. Mutmaidah. Introduksi Teknologi Sistem Tanam Jajar Legowo Jagung-Kedelai pada Lahan Sawah di Kabupaten Seluma. Prosiding Seminar Hasil Penelitian Tanaman Aneka Kacang dan Umbi 2017 VOl

29. Fatchiya, A., S. Amanah, dan Y. I. Kusumastuti. Jurnal Penyuluhan, 12(2):190-197 (2016)

30. A. Yudaningrum. Analisis hubungan proporsi pengeluaran dan konsumsi pangan dengan ketahanan pangan rumah tangga petani di Kabupaten Kulon Progo. Skripsi. Fakultas Pertanian Universitas Sebelas Maret. Surakarta (2011) 